\title{
Toluidine blue application to detect dysplasia and malignant changes in patients with oral lichenoid lesions
}

\author{
Oral likenoid lezyonlarda displazik ve malign değişimlerin \\ saptanması amacıyla biyopsi öncesinde toluidin mavisi uygulanması
}

\author{
Banu Taskin ${ }^{1}$, Bengu Gerceker Turk ${ }^{2}$, Gulsen Kandiloglu³ ${ }^{3}$ Can Ceylan ${ }^{2}$, Pelin Guneri ${ }^{4}$, Sibel Alper ${ }^{1}$, Tugrul Dereli² \\ ${ }^{1}$ Dept. of Dermatology, Koc University Hospital, Istanbul, Turkey, ${ }^{2}$ Dept. of Dermatology, Ege University, Faculty of Medicine, Izmir, Turkey, \\ ${ }^{3}$ Dept. of Pathology, Ege University, Faculty of Medicine, Izmir, Turkey, ${ }^{4}$ Dept. of Oral and Maxillofacial Radiology, Ege University, School of \\ Dentistry, Izmir, Turkey
}

\begin{abstract}
Background Oral lichen planus (OLP) is a chronic disease with immune-mediated pathogenesis which can be premalignant. Oral lichenoid dysplasia (OLD) is a precancerous process with lichenoid features which is frequently confused with OLP.

Objective In this study, we aimed to investigate the efficacy of toluidine blue (TB) administration before biopsy to detect the dysplastic changes in patients who were clinically diagnosed with OLP.

Methods Thirty consecutive patients with oral lichenoid lesions whose clinical findings were consistent with OLP were included in the study. Demographic and clinical characteristics of the patients studied were recorded and clinical photos were taken before and after the administration of TB. Areas to be biopsied were determined according to the results of the TB staining. Histopathologically, all the specimens were evaluated in terms of the diagnostic features of OLP and the presence of dysplastic findings.

Results The mean age of the 30 patients (21 females, 9 males) included in the study was 51.03 (26-70 years) and the median value of disease duration was $12.00 \pm 67.23$ months (2-360 months). Six patients (20.0\%) had positive staining after application of TB. Histopathological examination revealed OLP findings in 17 patients (56.7\%), OLP and dysplasia findings in nine patients (30.0\%) and lichenoid dysplasia in four patients (13.3\%). Dysplasia was detected in all of the lesions (six patients) which were stained blue with TB. The relationship between staining and dysplasia was significant $(\mathrm{p}<0.05)$. OLP and dysplasia were observed in four of these six patients $(66.7 \%)$, and lichenoid dysplasia was observed in the other two (33.3\%). The relationship between presence of dysplasia and presence of mitosis was found statistically significant in patients with histopathological dysplasia $(\mathrm{p}<0.05)$. When the presence of mitosis was evaluated in biopsies taken from the stained lesions, a statistically significant relation was found ( $\mathrm{p}<0.05)$.

Conclusions In our study, it was observed that dysplasia was detected in all stained areas after the application of TB to clinically classical OLP patients, but there was no staining in some patients despite the presence of dysplasia. Therefore, the sensitivity of the application was $46 \%$, specificity was $100 \%$, positive predictive value was $100 \%$ and negative predictive value was $70.8 \%$. TB application is a specific test to detect the dysplasia; however because of the low sensitivity in oral lichenoid lesions, another method is needed to increase the sensitivity.
\end{abstract}

Key words: Oral lichen planus, oral lichenoid dysplasia, Toluidine blue, dysplasia, oral lichenoid lesions

Corresponding author: Banu Taskin, Dept. of Dermatology, Koc University Hospital, Addres: Maltepe Mahallesi Topkapı Caddesi No:4. 34010, Topkapı, İstanbul, Turkey Phone: +90 85025082 50, E-mail: drbanutaskin@gmail.com, btaskin@kuh.ku.edu.tr

Received: 22 June 2018 Accepted: 29 September 2018

Conflicts of Interest: None

Funding: None 


\section{O̊zet}

Oral liken planus (OLP) immun aracılı patogeneze sahip, premalign olabilen kronik bir hastalıktır. Oral likenoid displazi (OLD) ise sıklıkla OLP ile karışan likenoid bulguların eşlik ettiği prekanseröz bir tablodur.

Amaç Bu çalışmada klinik olarak OLP tanısı alan hastalarda biyopsi alınmasından önce toluidin mavisi uygulamasının displastik değişiklikleri saptamadaki etkinliğinin araştırılması amaçlanmıştır.

Yöntem Çalışmaya klinik bulguları OLP ile uyumlu olan 30 hasta dahil edilmiştir. Çalışmaya alınan hastaların demografik ve klinik özellikleri kaydedilip, uygulama öncesi ve sonrasında klinik görüntüleme yapılmıștır. Biyopsi alınacak alanlar lezyonun toluidin mavisi ile boyama sonuçlarına göre belirlenmiştir. Histopatolojik olarak tüm preperatlar OLP'un tanısal özellikleri ve displazik bulguların varlı̆̆ açısından değerlendirilmiştir.

Bulgular 30 hastanın (21 kadın, 9 erkek) yaş ortalaması 51.03 (26-70 yaş), hastalık süresinin median değeri $12.00 \pm 67.23$ ay (2-360 ay) olarak saptand. Toluidin mavisi uygulamasından sonra altı hastada (\%20.0) mavi renkli tutulum izlendi. Histopatolojik incelemede 17 hastada OLP bulguları (\%56.7), dokuz hastada OLP ve displazi bulguları (\%30.0) ve dört hastada (\%13.3) likenoid displazi saptand. Mavi renkli boyanma izlenen lezyonların tümünde (altı hasta) displazi saptandı. Boyanma ile displazi arasındaki ilişki anlamlı olarak bulundu ( $\mathrm{p}<0.05)$. Bu hastaların dördünde (\%66.7) OLP ve displazi, ikisinde (\%33.3) likenoid displazi izlendi. Histopatolojik olarak displazi özelliği gösteren hastalarda displazi varlığı ile mitoz varlığı arasındaki ilişki istatistiksel olarak anlamlı bulundu $(\mathrm{p}<0.05)$. Boyanma gösteren lezyonlardan alınan biyopsilerde de mitoz varlığına bakıldığında istatistiksel olarak anlamlı ilişki tespit edildi $(\mathrm{p}<0.05)$.

Sonuçlar Çalışmamızda klinik olarak klasik OLP ile uyumlu hastalarda toluidin mavisi uygulanması sonrasinda boyanan tüm alanlarda displazi saptandığı, ancak displazi saptanan bazı hastalarda da boyanma olmadığı görülmüştür. Buna göre uygulamanın sensitivitesi \%46, spesifitesi \%100, pozitif prediktif değeri \%100, negatif prediktif değeri ise \%70.8 olarak bulunmuştur. Toluidin mavisi uygulaması displazinin saptanması için spesifik olmasına rağmen oral likenoid lezyonlardaki duyarlılığı düşüktür ve duyarlılığı arttırmak için yeni bir metoda ihtiyaç vardır.

Anahtar kelimeler: Oral liken planus, oral likenoid displazi, Toludin mavisi, displazi, oral likenoid lezyonlar

\section{Introduction}

Oral lichen planus (OLP) is a chronic inflammatory disease with immune-mediated pathogenesis. The prevalence of OLP is reported as $0.5 \%-2.2 \% .^{1,2}$ Spontaneous remission is rarely seen in the resistant cases and malign transformation has been reported to vary between $0 \%$ and $12.5 \%$ in the studies. ${ }^{3-7}$ Because of the chronic nature of the disease and the risk of malign transformation, it is recommended to follow these patients by regular controls. ${ }^{1,3,4,6-8}$ Oral lichenoid dysplasia (OLD) is a precancerous process with lichenoid features which is frequently confused with OLP. ${ }^{2}$

A variety of methods and devices are being developed to ensure early diagnosis of premalignant and malignant lesions that are difficult to distinguish. One of these is staining with toluidine blue stain. Toluidine blue (TB) is used as a dye for nucleic acids and this causes blue staining of cells with excessive mitosis. ${ }^{910}$ For this reason, TB application is used for determining early stage lesions which are likely to be malignant and can be unnoticed during clinical examination and determination of the biopsy area. ${ }^{10-15}$ In this study, we aimed to study the effectiveness of toluidine blue administration before biopsy to detect the dysplastic changes in OLP and OLD patients.

\section{Materials and Methods}

The study included 30 patients with oral lichenoid lesions (reticular lesions, also with irregular erosions or ulcerations whose ulcerative area is covered by a pseudomembranous veil). The procedures to be performed were explained and "patient informed consent form" was taken from all of them. Exclusion criteria were as follows: being younger than 18 years old, pregnancy or breastfeeding, allergy to any of the materials used in our study. 
The demographic characteristics of the patients, the duration of the disease (in months), clinical type (reticular, erosive, atrophic-erythematous, mixed), location of involvement, smoking were all recorded.

\section{Staining with toluidine blue}

Patients' In the study, 1\% tolonium chloride solution to be used for lesion staining was prepared as described by Mashberg et al. ${ }^{12}$ Solution: tolunium chloride (toluidine blue O) powder (Merck KGaA, Darmstadt, Germany) 1 gr; acetic acid $10 \mathrm{ml}$ (Merck KGaA, Darmstadt, Germany); $4.19 \mathrm{ml}$ of absolute alcohol (Merck KGaA, Darmstadt, Germany); distilled water, rounding up to $100 \mathrm{ml}$. The $\mathrm{pH}$ value is adjusted to be 4.5 or less with acetic acid.

The rinsing procedure was carried out as follows: Rinsing with $1 \%$ acetic acid for 20 seconds; rinsing with water for 20 seconds, twice; rinsing mouth with $5-10 \mathrm{ml}$ of $1 \%$ tolonium chloride solution for 20 seconds; rinsing with acetic acid for 1 minute; rinsing with water.

The dye involvement was considered as "positive" in areas separated by coloration of blue tones from the normal mucosa. Blue staining filling fissures and ulcerative areas were not considered as positive. Biopsies were taken from the stained areas. The stained areas were kept in separate cups and the examining pathologist was not informed about the staining. Samples were fixed with buffered 10\% formalin and hematoxylen-eosin staining procedures were completed with routine procedures and examined under light microscope.

\section{Histologic evaluation of biopsy material}

Histopathologically, all of the preparates were evaluated in terms of modified diagnostic OLP criteria by WHO at 2003 (liquefaction degeneration, band-like lymphocyte accumulation, maturation status, sawtooth appearance in rete, colloid body presence, hyperkeratosis) and the diagnostic exclusion findings (lack of basal cell liquefaction, heterogeneous infiltration, presence of atypia, presence of mitosis, blunting in rete, presence of diskeratosis and deep inflammation). Patients with clinically OLP findings were evaluated according to the histopathological evaluation: (i) Those which have the diag- nostic features of OLP as "OLP", (ii) those which have OLP findings, as well as dysplasia findings as "OLP and dysplasia", (iii) those without OLP findings but bearing band-like lymphohistiocytic infiltration in lamina propria and having dysplastic features were separated as "lichenoid dysplasia (LD)". "Dysplasia" was considered to be positive for at least two of the atypical cytomorphological findings (nuclear enlargement or hyperchromasia, increase in dyskeratosis, mitotic figures and aberrant mitosis), and topographic changes (blunting of rete tips, absence of liquefaction in basal cells and sequencing disorder).

\section{Statistical analysis of data}

The demographic and clinical characteristics of the patients, staining with toluidine blue and distribution of the histopathologic results were evaluated statistically. Relationship between staining and clinical features, between presence of dysplasia and clinical features, between histopathological features and staining were compared. Statistical analysis of the obtained data was performed by using "SPSS for Windows 15.0" program in computer. Statistical evaluation of the results was done using Mann Whitney U test and Chi-square tests. When $\mathrm{p}<0.05$, the difference was considered significant.

\section{Results}

Of the 30 patients included in the study, 21 (70\%) were female and $9(30 \%)$ were male. The mean age of the patients was 51.03 (between 26-70 years). Duration of disease ranged from 2-360 months (median $12.00 \pm 67.23$ months). It was found that $16.7 \%$ of the patients were between the ages of 18-39, 73\% were between the ages of $40-59$ and $10 \%$ were 60 years old and above.

Eleven of the patients (36.7\%) had reticular type and 19 had mixed type. Regarding the location of the lesions, 29 patients (96.7\%) had at least one buccal mucosal involvement. This was followed by tongue (46.0\%), gingiva (30.0\%), palate (20.0\%) and lip (10.0\%) involvements.

Six patients (20.0\%) had blue staining after administration of TB. Histopathological examination of the lesions revealed OLP findings (56.7\%) in 17 patients, OLP and dysplasia findings in nine patients (30.0\%) and li- 
Table 1. Toluidine blue staining and histopathologic results

\begin{tabular}{|c|c|c|c|c|c|}
\hline Staining & $\begin{array}{l}\text { OLP } \\
\text { n (\%) }\end{array}$ & $\begin{array}{c}\text { OLP and } \\
\text { dysplasia } \mathrm{n}(\%)\end{array}$ & $\begin{array}{c}\text { Lichenoid dysplasia } \\
\text { n (\%) }\end{array}$ & $\begin{array}{l}\text { Total } \\
\mathrm{n}(\%)\end{array}$ & $\mathrm{P}$ value \\
\hline+ & $0(0)$ & $4(66.7)$ & $2(33.3)$ & $6(100)$ & \\
\hline - & $17(70.8)$ & $5(20.8)$ & $2(8.3)$ & $24(100)$ & 0.007 \\
\hline Total n (\%) & $17(56.7)$ & $9(30.0)$ & $4(13.3)$ & $30(100)$ & \\
\hline
\end{tabular}

chenoid dysplasia in four patients (13.3\%). Of the 13 patients with dysplasia, five (38.5\%) were of pure reticular type, whereas eight of them had mixed type (61.5\%) lesions. There was no significant relationship between presence of dysplasia and clinical type and oral extension ( $p>0.05$ ). Dysplasia was detected in $42.9 \%$ of women and $44.4 \%$ of men. The relationship between gender and development of dysplasia was not significant ( $p>$ 0.05). It was observed that dysplasia increased with age, but there was no statistically significant relation between dysplasia and age groups ( $p>0.05)$. There was no significant relationship between the presence of dysplasia and the duration of lesions, location and smoking ( $>0.05)$.

Dysplasia was detected in all of the lesions stained in blue color (six patients). The relationship between staining and dysplasia was significant $(\mathrm{p}=0.007)$ (Fig. la, lb). OLP and dysplasia in 4 patients (66.7\%) and lichenoid dysplasia in two patients (33.3\%) were observed (Table 1). A further biopsy was taken from another clinically suspicious area in four of the patients, who had TB staining, and two of them had OLP with no staining and the other two had dysplasia without staining. There was no significant relationship between staining and clinical types ( $p>0.05)$. In the administration of TB, the sensitivity of the procedure was found to be $46 \%$, specificity $100 \%$, positive predictive value $100 \%$ and negative predictive value $70.8 \%$ in order to detect dysplasia.

The relationship between presence of dysplasia and presence of mitosis was found statistically significant in patients with histopathological dysplasia $(\mathrm{p}=0.000)$ (Table 2). Statistically significant correlation was found between biopsies taken from lesions showing staining and mitosis $(\mathrm{p}=0.000)$ (Table 3$)$.

\section{Discussion}

In the previous studies, OLP was found to be more frequent in 5th-6th decades of life and more in women than men. ${ }^{16-18}$ Our study revealed that OLP was more frequent in female gender (70\%) and more frequent in ages of $40-59$ (73\%), consistent with other studies

Table 2. The relationship between dysplasia and mitosis

\begin{tabular}{|c|c|c|c|c|}
\hline \multirow{2}{*}{ Dysplasia } & \multicolumn{2}{|c|}{ Mitosis } & \multirow{2}{*}{ Total n (\%) } & \multirow{2}{*}{$P$ value } \\
\hline & $+\mathrm{n}(\%)$ & - n (\%) & & \\
\hline+ & $9(69.2)$ & $4(30.8)$ & $13(100)$ & \\
\hline- & $1(4.8)$ & $20(95.2)$ & $21(100)$ & 0.000 \\
\hline Total n (\%) & $10(29.4)$ & $24(70.6)$ & $34(100)$ & \\
\hline
\end{tabular}


Table 3. The relationship between staining and mitosis

\begin{tabular}{ccccc}
\hline \multirow{2}{*}{ Staining } & \multicolumn{2}{c}{ Mitosis } & Total n (\%) & P value \\
\cline { 2 - 3 }+ & $+\mathrm{n}(\%)$ & $-\mathrm{n}(\%)$ & & \\
- & $6(66.7)$ & $2(33.3)$ & & \\
Total n (\%) & $10(29.4)$ & $24(70.6)$ & $34(100)$ & 0.048 \\
\hline
\end{tabular}

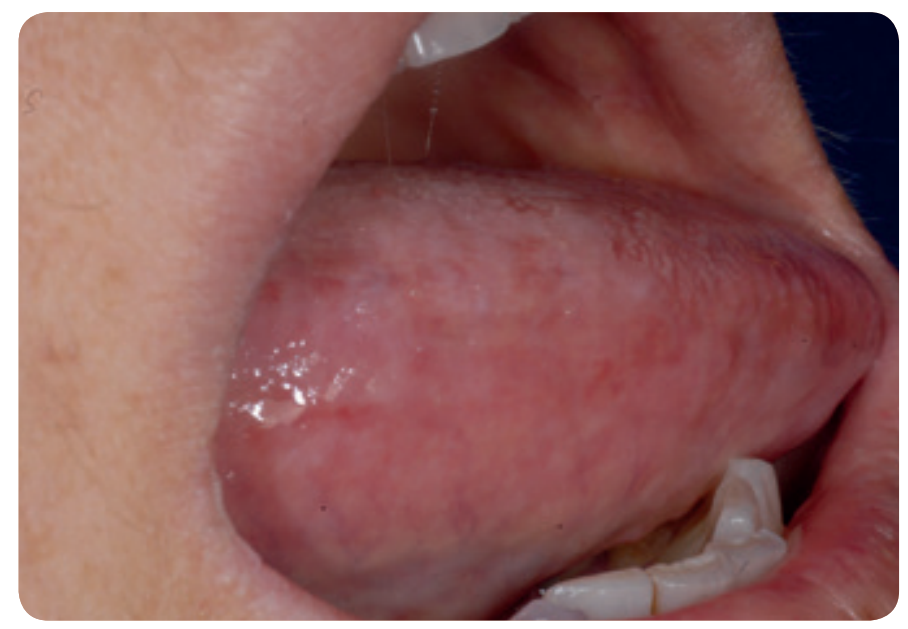

Fig. 1a. Clinical apparence of right side of the tongue

in the literature. Characteristic reticular appearance of OLP can be observed alone or in combination with erythematous and erosive lesions. ${ }^{1-3,16,17,19,20}$ In this study, the most common type was the mixed type (63.3\%). Consistent with the literature, buccal mucosa was the most frequently affected area, followed by tongue and gingiva. ${ }^{3,16,17}$

Although it has been shown that erosive lesions occur at older ages, especially when the disease duration is longer, ${ }^{3,16,17}$ there was no significant relationship between clinical type and age of the patients and duration of illness in our study. This might be caused by the small number of study group.

Despite the large number of studies with OLP, the clinical and histopathological criteria for OLP diagnosis

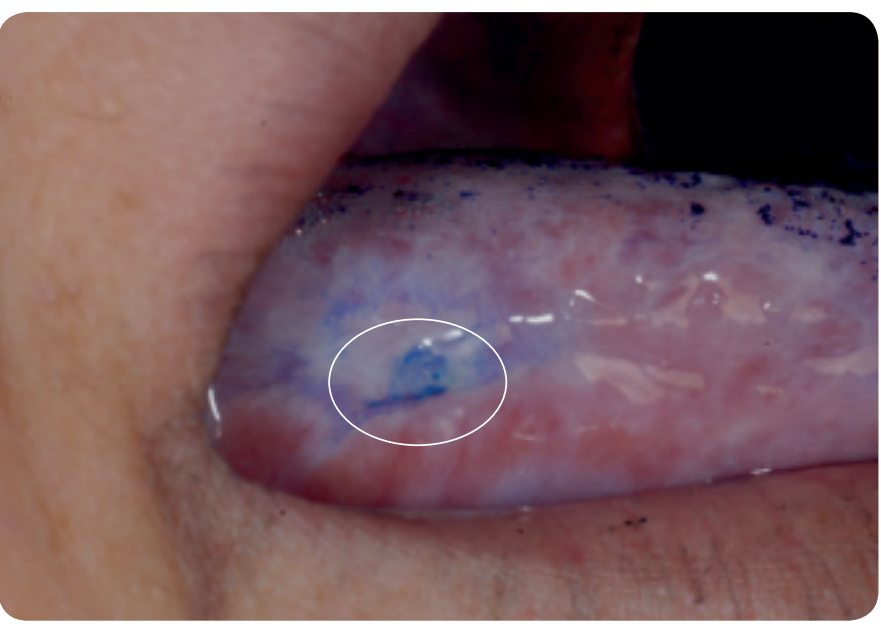

Fig. 1b. Dysplasia was detected in the lesion stained in blue color (marked) (Positive staining)

and differential diagnosis are still being discussed. Correlation of clinical and histopathological findings are required for the diagnosis of OLP. ${ }^{4,8,16,21}$ Oral lichenoid lesions (OLL) are clinically and histopathologically similar lesions to OLP. OLL may occur as drug-related, as contact sensitivity to dental materials, or as part of chronic GVHD. OLLs tend to be unilateral, unlike OLP, and erosive areas may also reside outside trauma areas. ${ }^{1,4}$ The lesions were symmetric in $90 \%$ of our patients included in our study. Classical reticular lesions were accompanied in all patients while erosive areas were located in the lateral part of the tongue and in areas that fit the sharp edges of the teeth. There is often an apparent anatomic relationship between the lesion and the material in OLLs associated with dental materials. In our study, these patients were diagnosed as OLP because 
of the presence of widespread lesions clinically; and histopathologically, because of the presence of findings supporting OLP (liquefaction degeneration in the basal layer and band-like lymphocyte infiltration) and because of the absence of the heterogeneous infiltration typical for OLL histopathologically. Unlike OLP, in OLL, more dense plasma cells than lymphocytes which include eosinophils and plasma cells are observed. ${ }^{1,4,22}$ Despite all of these differences, there is no clinical or histopathologic distinction between OLL and OLP in some cases. ${ }^{4}$ Some authors agree that OLL is the OLP variant triggered by systemic drug use or dental materials exposure. ${ }^{23}$ OLL; accepted as an OLP variant, or as a separate entity, the results in the studies showed that malignant transformation developed in these lesions. ${ }^{6-8,24}$ Aguirre Urizar recommended that all lichenoid lesions located in the oral mucosa should be called "Or al lichenoid disease" in order to elucidate the complexity in the terminology and classify the mentioned clinical tables as subtypes of oral lichenoid disease. ${ }^{25}$

In some studies, it has been reported that the frequency of malign transformation associated with OLP ranges from $0 \%$ to $12.5 \%{ }^{6}$ A recently reported metaanalysis found that the rate of squamous cell carcinoma (SCC) associated with true OLP lesions was $1.1 \%{ }^{18}$ The reason for the high rate of malign transformation in some of the studies may be the reason of the establishment of OLP diagnosis in terms of clinical findings which may be also observed in "lichenoid dysplasia" as in our study, 8,26 Epithelial dysplasia found in OLP patients have been explained by two conditions by Lodi et al $;{ }^{27}$ clinically OLP-compatible lesions with accompanying dysplasia or lichenoid histopathological features (especially band-like lymphocyte infiltration) without classical clinical OLP findings (non-reticular appearance and unilateral placement). They evaluated that typical OLPcompatible lesions with dysplasia may be the early phases of OLP with malign transformation. While these debates continue, new studies indicate that the most objective pathway for determining the risk of dysplasia and malignant transformation is the genetic studies. , $28,29^{2}$ In our study, $43.3 \%$ of the patients had findings of dysplasia and 30\% of the patients had OLP and dysplasia findings together. Urbizo-Velez et al. ${ }^{30}$ have reported dysplasia in $11 \%$ of the OLP cases, while De Jong et al. ${ }^{31}$ have reported in $25 \%$. The fact that the rate of dysplasia in our group of patients with classical OLP lesions is higher than the literature attributed to the fact that our hospital is providing tertiary care and evaluated selected patients. Our patients with classical OLP clinic and histopathological liquefaction degeneration, band-like lymphocyte infiltration and atypia findings are considered to be in the early stage of malign transformation in OLP. In genetic studies, loss of heterozygosity detected in SCC has been shown to be prominent in OLP cases with dysplasia and in these cases risk of malignancy increases. ${ }^{21}$

In the $55.6 \%$ of the OLP patients who had developed severe dysplastic changes and/or developed SCC; changes were found to be multiple and multifocal and similar to the other head and neck cancers, thus oral field cancerization should be considered in OLP. ${ }^{5}$ Another important point is that the microscopic changes seen in histopathologically diagnosed cases of lichenoid dysplasia were related only to the area in which the biopsy was taken. ${ }^{31}$ Because of all the reasons mentioned above, close follow-up of patients is recommended for

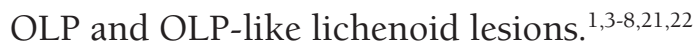

Toluidine blue is a vital dye used along with clinical examination in the early diagnosis of oral premalignant and malignant lesions for many years. ${ }^{11}$ In our study, prior to the diagnostic biopsy procedure in patients whose clinic findings were compatible with OLP, rinsing with toluidine blue procedure was applied to detect possible dysplastic changes and the location of the appropriate biopsy area. It was observed that dysplasia was detected in all stained areas after application, but there was no staining in some patients who revealed dysplasia without a positive TB stain. Accordingly, the sensitivity value of the procedure was found as $46 \%$, specificity as $100 \%$, positive predictive value as $100 \%$ and negative predictive value as $70.8 \%$. Sensitivity and specificity of toluidine blue administration differ in the literature: Onofre et al. reported that TB application 
in the literature varies between $44-100 \%$ as for the specificity of detecting premalign/malign lesions and 77 $100 \%$ as for the sensitivity in their study. ${ }^{32}$ These studies were performed in high-risk premalign and malign lesions. Experience with dye application in lichenoid lesions is limited to observations of limited numbers of OLP and OLL patients included into the studies. The high specificity value of our study compared to studies in the literature has been attributed to the exclusion of ulcerative lesions that may give false positive results (Figure 2a, 2b)

The differences between the results of studies investigating the efficacy of TB application are probably due to the heterogeneity of the analyzed samples and due to the experience of the researchers in evaluating the stained lesions. Mashberg suggests that all even light blue stained lesions should be considered suspicious until the biopsy shows the opposite. ${ }^{12}$

OLP lesions are usually poorly stained with toluidine blue and meaning of this finding varies in the literature. Epstein et al. revealed that weakly stained lesions should also be carefully assessed. ${ }^{33}$ Guo et al. showed that $59 \%$ of the lesions which were identified as "false-positive" after staining with toluidine blue and assessed as benign in histologic evaluation showed loss of heterozygosity. Researchers have shown that chromosomal changes in these lesions with histologic features

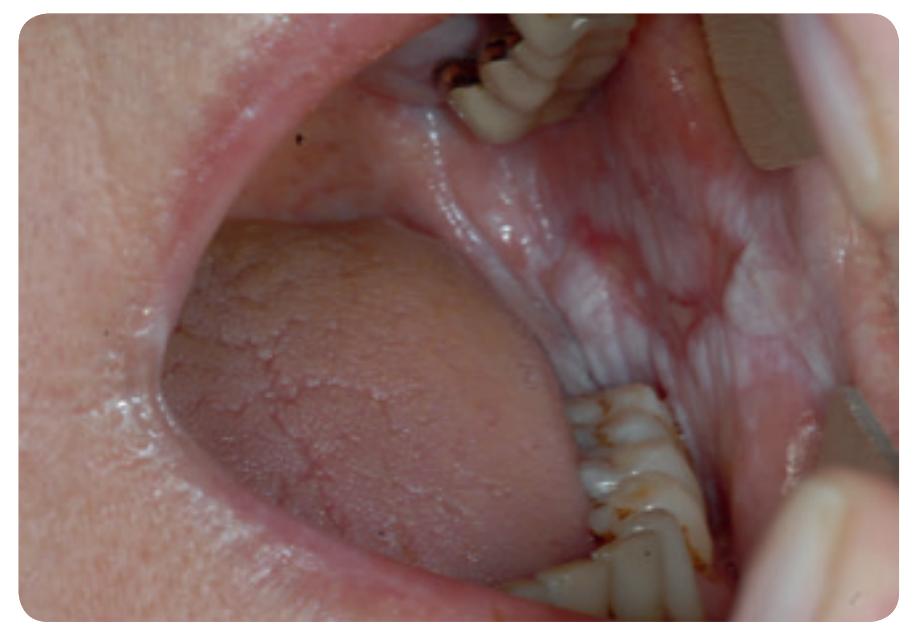

Fig. 2a. Clinical apparence of erosive lesions of benign features are actually correctly diagnosed by toluidine blue. ${ }^{34}$ Gandolfo et al. observed that dark blue staining was observed in lesions with excessive nuclear involvement and that staining was not associated with any histological features in light blue stained lesions. ${ }^{11}$

Lichenoid lesions, which were stained darker compared to normal mucosa with toluidine blue but not as much darker as described in the literature detected in the patients included to our study, were accepted as significant, and histopathologically, the dysplastic changes were observed in their pathology. (Figure 3a, 3b). Some researchers report that hyperkeratinized areas do not stain, but erythroplasia and carcinomas are stained with dark blue color due to keratinization loss and increased DNA content in the unit. Besides, it is indicated that necrotic parts and submucosal extensions of the large or symptomatic carcinomas are not stained due to keratin do not allow dye to penetrate. ${ }^{33}$ In our study, it was observed that there was no staining in some patients with dysplasia and when these non-stained preparations were examined again, it was observed that hyperkeratosis was clearly observed in these lesions.

Gandolfo et al. have shown that some benign lesions can also be stained dark blue. However, staining similar to the epithelial nuclear involvement in carcinoma could also be seen in the granulation tissue, which may be due to the tendency of the nuclei of proliferating epithelial

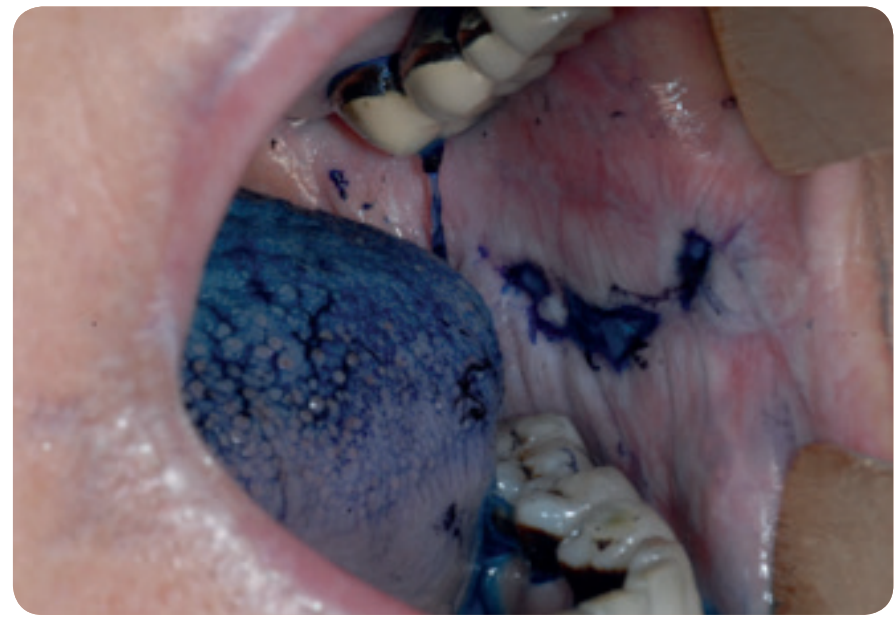

Fig. 2b. Dye accumulation in erosive areas after staining with toluidine blue (negative staining) 


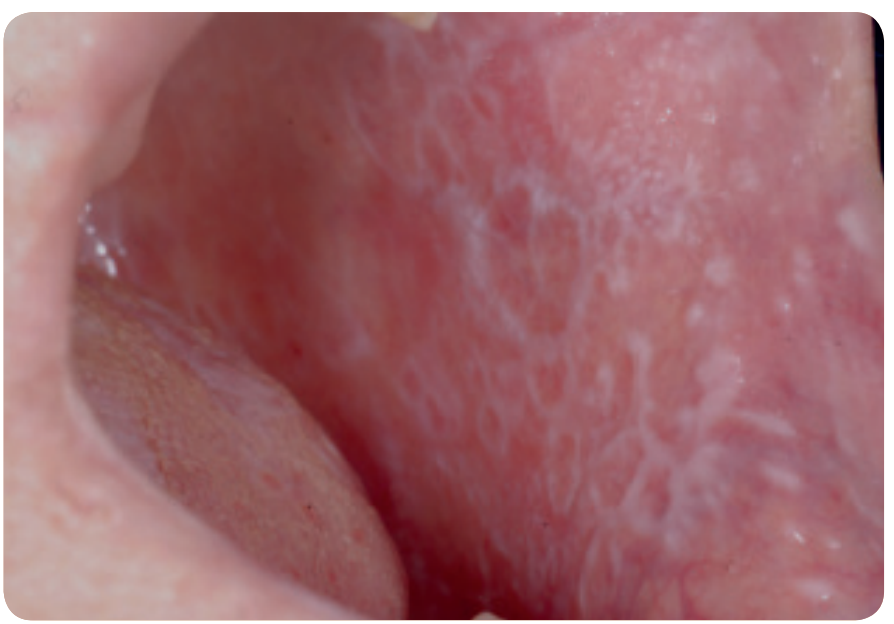

Fig. 3a. Clinical apparence of reticular OLP lesions on the left buccal mucosa

cells to stain. ${ }^{11}$ According to Mashberg, healthy tissue is not stained. There may be excess paint remained in the gingival cavities and in areas covered by superficial debris in the lingual dorsum. In order to avoid this situation, it is suggested to clean these areas during the last two steps of acetic acid rinsing and during rinsing with water. ${ }^{12}$ It has been reported that $100 \%$ false-positive results are obtained in ulceration fields in the administration of TB. In our study, staining in these areas was excluded from the evaluation.

The reason for the involvement of the TB in the dysplastic lesions and in the malignant cells is due to the increase in the density of the nuclear material ${ }^{35,36}$, the deterioration of cell cohesion ${ }^{37}$, and the increase in mitosis. ${ }^{15,38}$ In our study, consistent with the literature, there was a significant correlation between staining with TB and histopathological presence of mitosis.

During our study, the main difficulties with regard to the administration of the method have been found to be the unpleasant taste of the dyeing solution and acetic acid, and intense staining in the mouth tissues lasting 1-2 days in some patients.

In conclusion, this study has the largest group of patients with TB staining in order to detect dysplasia in OLP lesions in the accessible literature. TB staining method is an easy, simple, inexpensive and rapid method to apply in other oral premalign and malign lesions

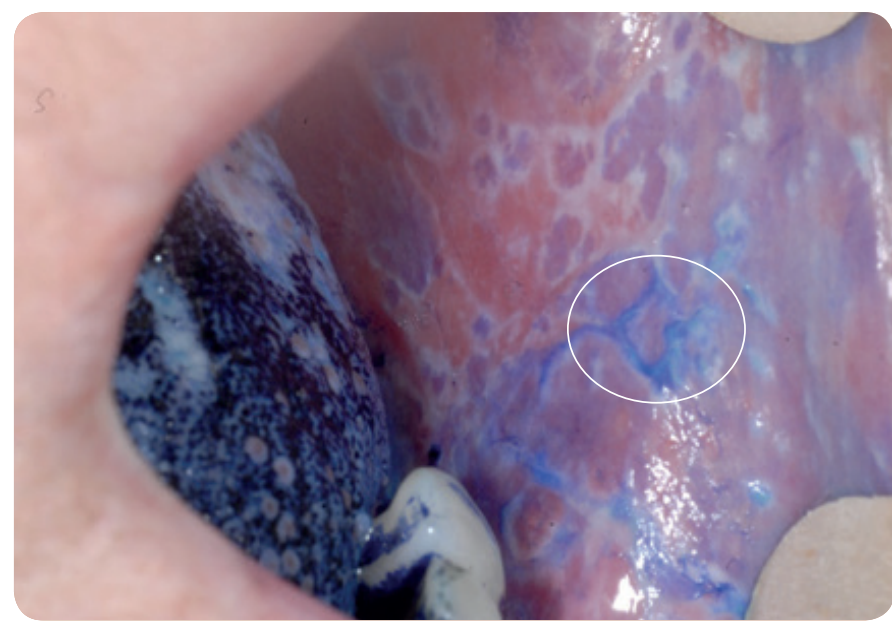

Fig. 3b. Light blue stained areas after application of toluidine blue (positive staining)

as well as in lichenoid lesions. TB application is a specific test to detect the dysplasia; however because of the low sensitivity (46\%) in oral lichenoid lesions, another method is needed to increase the sensitivity in lichenoid lesions.

\section{References}

1. Al-Hashimi I, Schifter M, Lockhard PB, et al. Oral lichen planus and lichenoid lesions: diagnostic and therapeutic considerations. Oral Surg Oral Med Oral Pathol Oral Radiol Endod 2007;103:1-12.

2. Chandrakala J, Vidya M, Hemavathy S, Srinath S, Suresh T, Yadav TS. Estimation of silver nucleolar organizer regions in oral lichen planus, oral lichenoid reactions and oral lichenoid dysplasia. J Oral Maxillofac Pathol 2017;21:454.

3. Eisen D. The clinical features, malignant potential, and systemic associations of oral lichen planus: A study of 723 patients. J Am Acad Dermatol 2002;46:207-14.

4. Ismail SB, Kumar SKS, Zain RB. Oral lichen planus and lichenoid reactions: etiopathogenesis, diagnosis, management and malignant transformation. J Oral Sci 2007;49:89-106.

5. Mignogna MD, Fedele S, Lo Russo L, Mignogna C, de Rosa G, Porter SR. Field cancerization in oral lichen planus. EJSO 2007;33:383-9.

6. Gonzalez-Moles MA, Scully C, Gil-Montoya JA. Oral lichen planus: controversies surrounding malignant transformation. Oral Diseases 2008;14:229-43.

7. Gonzalez-Moles MA, Gil-Montoya JA, Ruiz-Avila I, 
Bravo M. Is oral cancer incidence among patients with oral lichen planus/oral lichenoid lesions underestimated? J Oral Pathol Med 2017;46:148-53.

8. van der Meij EH, Schepman KP, van der Waal I. The posibble premalignant character of oral lichen planus and oral lichenoid lesions: A prospective study. Oral Surg Oral Med Oral Pathol Oral Radiol Endod 2003;96:164-71.

9. Chieco P, Pagnoni M, Romagnoli E, Melchiorri C. A rapid and simple staining method, using toluidine blue, for analysing mitotic figures in tissue sections. Histochem J 1993;25:569-77.

10. Patton LL, Elter JR, Southerland JH, Strauss RP. Knowledge of oral cancer risk factors and diagnostic concepts among North Carolina dentists. JADA 2005; 136:602-10.

11. Gandolfo S, Pentenero M, Brocoletti R, et al. Toluidine blue uptake in potentially malignant oral lesions in vivo: Clinical and histological assessment. Oral Oncol 2006;42:89-95.

12. Mashberg A. Final evaluation of tolonium chloride rinse for screening of high-risk patients with asymptomatic squamous carcinoma. JADA 1983;106:319-23.

13. McIntyre G.T, Oliver R.J. Update on precancerous lesions. Dent Update 1999;26:382-6.

14. Missmann M, Jank Siegfried J, Laimer K, Gassner R. A reason for the use of toluidine blue staining in the presurgical management of patients with oral squamous cell carcinomas. Oral Surg Oral Med Oral Pathol Oral Radiol Endod 2006;102:741-3.

15. Siddiqui IA, Farooq MU, Siddiqui RA, Rafi SMT. Role of toluidine blue in early detection of oral cancer. Pak J Med Sci 2006;22:184-7.

16. Xue J-L, Fan MW, Wang S-Z, Chen X-M, Li Y, Wang L. A clinical study of 674 patients with oral lichen planus in China. J Oral Pathol Med 2005;34:467-72.

17. Ingafou M, Leao JC, Porter SR, Scully C. Oral lichen planus: a retrospective study of 690 British patients. Oral Dis 2006;12:463-8.

18. Aghbari SMH, Abushouk AI, Attia A, et al. Malignant transformation of oral lichen planus and oral lichenoid lesions: A meta-analysis of 20095 patient data. Oral Oncol 2017;68:92-102.

19. Scully C, Eisen D, Carrozzo M. Management of oral lichen planus. Am J Clin Dermatol 2000;1:287-306.

20. Au J, Patel D, Campbell JH. Oral lichen planus. Oral Maxillofac Surg Clin North Am 2013;25:93-100.

21. Epstein JB, Wan LS, Gorsky M, Zhang L. Oral lichen planus: Progress in understanding its malignant potential and the implications for clinical management. Oral Surg Oral Med Oral Pathol Oral Radiol Endod 2003;96:32-7.

22. Kamath VV, Setlur K, Yerlagudda K. Oral Lichenoid Lesions - A Review and Update. Indian J Dermatol
2015;60:102.

23. Rice PJ, Hamburger J. Oral lichenoid drug eruptions: their recognation and management. Dent update 2002;29:442-7.

24. Larsson A, Warfvinge G. Malignant transformation of oral lichen planus. Oral Oncol 2003;39:630-1.

25. Aguirre Urizar JM. Letter to the editor: Oral Lichenoid Disease. A new classification proposal. Med Oral Patol Oral Cir Bucal 2008;13:224.

26. Krutchkoff DJ, Eisenberg E. Lichenoid dysplasia: a distinct histopathologic entity. Oral Surg Oral Med Oral Pathol Oral Radiol Endod 1985;30:308-15.

27. Lodi G, Scully C, Carrozzo M, Griffiths M, Sugerman PB, Thongprasom K. Current controversies in oral lichen planus: report of an international consensus meeting. Part 2. Clinical management and malignant transformation. Oral Surg Oral Med Oral Pathol Oral Radiol Endod 2005;100:164-78.

28. Sperandio MS, Klinikowski MF, Brown AL, et al. Image-based DNA ploidy analysis aids prediction of malignant transformation in oral lichen planus. Oral Surg Oral Med Oral Pathol Oral Radiol 2016;121:643-50.

29. Yang Q, Sun H, Zhang J, et al. Identification of the key genes implicated in the transformation of OLP to OSCC using RNA-sequencing. Oncol Rep 2017;37:2355-65.

30. Urbizo-Vélez J, Rodriguez Pérez I, Albrecht M, Bánóczy J. Comparative histopathological studies in oral lichen planus. Acta Morphol Hung 1990;38:7181.

31. De Jong WF, Albrecht M, Bánóczy J, van der Waal I. Epithelial dysplasia in oral lichen planus. A preliminary report of a Dutch-Hungarian study of 100 cases. Int J Oral Surg 1984;13:221-5.

32. Onofre MA, Sposto MR, Navarro CM. Reliability of toluidine blue application in the detection of oral epithelial dysplasia and in situ and invasive squamous cell carsinomas. Oral Surg Oral Med Oral Pathol Oral Radiol Endod 2001;91:535-40.

33. Epstein JB, Zahng L, Poh C, et al. Increased allelic loss in toluidine blue positive oral malignant lesions. Oral Surg Oral Med Oral Pathol Oral Radiol Endod 2003;95:45-50.

34. Guo Z, Yamaguchi K, Sanchez-Cespedes M, et al. Allelic losses in OraTest-directed biopsies of patients with prior upper aerodigestive tract malignancy. Clin Cancer Res 2001;7:1963-8.

35. Herlin P, Marnay J, Jacob JH, Ollivier JM, Mandard AM. A study of the mechanism of the toluidine blue dye test. Endoscopy 1983;15:4-7.

36. Shedd DP, Hukill PB, Bahn S. In vivo staining characteristics of oral cancer. Am J Surg 1965;110:631-4.

37. Strong MS, Incze J, Vaughan CW. Field cancerization in the aerodigestive tract: its etiology, manifestation, 
and significance. J Otolaryngol 1984;13:1-6.

38. Vercellino V, Gandolfo S, Camoletto D, Griffa B, Mori C. Toluidine blue (tolonium chloride) in the early diagnosis of dysplasias and carcinomas of the oral mucosa. Minerva Stomatol 1985;34:257-61. 